\title{
Effect of biostimulator Aminoplant mixtures with herbicides on sugar beet yield and quality
}

\author{
Wpływ łącznego stosowania biostymulatora Aminoplant z herbicydami \\ na wielkość i jakość plonu buraka cukrowego
}

\author{
Roman Kierzek, Marta Dubas, Kinga Matysiak
}

\begin{abstract}
Summary
Experiments were conducted at the Experimental Field Station of the Institute of Plant Protection - National Research Institute in Winna Góra, in 2011-2012. The aim of the study was to assess the effects of biostimulator Aminoplant on the development and yield of sugar beet and the activity of herbicides. The primary protection from weed control was treatments with a mixture of two herbicides Betanal EC 274 Elite with Safari 50 WG in three terms, in the split dose. Aminoplant applied two or three times together with herbicides and three times in a single operation. The application of Aminoplant increased the yield of sugar beet roots, but had no significant effect on the quality parameters of sugar beet roots like sugar, sodium, nitrogen and potassium content. The addition of biostimulator Aminoplant to herbicides had no negative effect on treatment efficacy and phytotoxicity against sugar beet plants. Aminoplant application date and number of treatments should be adjusted to the possibilities of chemical weed control and the appropriate growth stage of sugar beet.
\end{abstract}

Key words: sugar beet, combined treatment, Aminoplant, biostimulator, weed infestation, herbicides

\begin{abstract}
Streszczenie
Badania przeprowadzono w latach 2011-2012 na terenie Polowej Stacji Doświadczalnej Instytutu Ochrony Roślin - Państwowego Instytutu Badawczego w Winnej Górze. Celem badań była ocena efektów działania nawozu organicznego o cechach biostymulatora Aminoplant na rozwój i plonowanie buraka cukrowego $w$ zabiegach łącznych $z$ herbicydami. Podstawową ochronę przed zachwaszczeniem stanowiły zabiegi z użyciem mieszaniny dwóch herbicydów Betanal Elite 274 EC z Safari 50 WG w trzech terminach, w ramach dawek dzielonych. Środek Aminoplant użyto dwu- lub trzykrotnie łącznie z herbicydami oraz trzykrotnie w zabiegu pojedynczym. Stosowanie biostymulatora Aminoplant wpłynęło na zwiększenie wielkości plonu korzeni buraka cukrowego, natomiast nie miało istotnego wpływu na parametry jakościowe korzeni buraka cukrowego, takie jak: cukier, azot, sód i potas. Dodatek biostymulatora Aminoplant nie miał wpływu na efektywność chwastobójczą i fitotoksyczność herbicydów w stosunku do roślin buraka cukrowego. Termin stosowania środka Aminoplant i liczbę zabiegów należy dostosować do możliwości chemicznej ochrony przed chwastami i odpowiedniej fazy rozwojowej buraka cukrowego.
\end{abstract}

Słowa kluczowe: burak cukrowy, zabiegi łączne, Aminoplant, biostymulator, zachwaszczenie, herbicydy

Instytut Ochrony Roślin - Państwowy Instytut Badawczy

Zakład Herbologii i Techniki Ochrony Roślin

Władysława Węgorka 20, 60-318 Poznań

r.kierzek@iorpib.poznan.pl 


\section{Wstęp / Introduction}

Badania naukowe wykazują korzystny wpływ biostymulatorów i środków zawierających dodatki mikroelementów na potencjał plonotwórczy roślin uprawnych (Przybysz i wsp. 2010; Gawrońska i Przybysz 2011). Często to pozytywne działanie ujawnia się $\mathrm{W}$ sytuacji występowania silnego stresu abiotycznego. Niektóre biostymulatory zwiększają tolerancję roślin na szkodliwe bodźce płynące ze środowiska, w tym przede wszystkim na suszę (Gawrońska i Przybysz 2011). Pożądaną cechą niektórych preparatów, stosowanych np. łącznie $\mathrm{z}$ herbicydami jest poprawa tolerancji rośliny uprawnej na środek chwastobójczy (Kositornai Smoliński 2002; Anyszka i wsp. 2008). Jednym z takich związków o charakterze biostymulacyjnym jest Aminoplant znany również jako Siapton (Cambri i wsp. 2008; Gawrońska i Przybysz 2011). Jak donoszą Krajewska i Latkowska (2008) ma on korzystny wpływ na wzrost roślin poprzez podwyższenie poziomu tolerancji/odporności roślin na stresy abiotyczne (zasolenie, zanieczyszczenia, temperatura, susza). Znajduje się w nim 18 różnych aminokwasów pochodzących $\mathrm{z}$ hydrolizy białek zwierzęcych (Bytniewska 1985; Cambrii i wsp. 2008). Aminoplant działa również pośrednio na poprawę aktywności niektórych układów enzymatycznych oraz regulację niektórych funkcji regulatorów wzrostu roślin (PGR - Plant Growth Regulator) i procesów biochemicznych. Ponadto ułatwia wchłanianie i transport składników odżywczych makro- i mikroelementów. Stwierdzenia te pozwalają określić Aminoplant jako, więcej niż prosty organiczny nawóz dolistny (Maini 2000). W doświadczeniach, które zostały przeprowadzone w buraku cukrowym, ziemniaku, truskawce, zbożach, na owocach cytrusowych, w uprawach ogrodniczych, pomidorze, winorośli, bawełnie, itp. stwierdzono pozytywny wpływ stosowania biostymulatora Aminoplant (Maini 2000; Grabowska i wsp. 2012).

Celem badań była ocena efektów działania stymulatora Aminoplant na rozwój i plonowanie buraka cukrowego w zabiegach łącznych $\mathrm{z}$ herbicydami. Poszukiwano także optymalnego sposobu i terminu stosowania tego środka.

\section{Materiały i metody / Materials and methods}

W roku 2011 i 2012 na terenie Polowej Stacji Doświadczalnej Instytutu Ochrony Roślin - Państwowego Instytutu Badawczego w Winnej Górze, założono ścisłe doświadczenia polowe w uprawie buraka cukrowego. Doświadczenia przeprowadzono na poletkach o powierzchni $24,75 \mathrm{~m}^{2}(2,25 \mathrm{~m} \times 11 \mathrm{~m})$, w 4 powtórzeniach. Przedplonem były zboża ozime (odpowiednio pszenica i pszenżyto). Doświadczenia założono na glebie płowej wytworzonej z piasków gliniastych średnich, klasy bonitacyjnej IIIa.

Do pierwszych dwóch zabiegów (T1 i T2 - odpowiednio widoczna pierwsza para nierozwiniętych liści buraka oraz faza 2 liści buraka) na chwasty w fazie liścieni zastosowano mieszaninę Kemifam Super Koncentrat $320 \mathrm{EC}$ (fenmedifam + desmedifam) w dawce 0,72 1/ha +
Kosynier 420 EC (chlorydazon + chinomerak) (1 1/ha) + Metafol 700 SC (metamitron) $(1,25 \mathrm{l} / \mathrm{ha})$.

Zasadniczą ochronę przed zachwaszczeniem stanowiły zabiegi $\mathrm{z}$ użyciem herbicydów w trzech zabiegach (T3-T5), w ramach dawek dzielonych. Aminoplant stosowano dwu- lub trzykrotnie, dodając go do zabiegów z użyciem mieszaniny dwóch herbicydów Betanal Elite 274 EC (desmedifam + fenmedifam + etofumesat) z Safari $50 \mathrm{WG}$ (triflusulfuron) w dawkach 1,0 1/ha $+30 \mathrm{~g} / \mathrm{ha}$. W badaniach oceniano ponadto efekt działania biostymulatora Aminoplant w zabiegu oddzielnym. Jedna z kombinacji została wzbogacona o łączne zastosowanie dodatków nawozowych (Basfoliar 36 Extra + ADOB Bor + ADOB Mn). Jako środka porównawczego użyto biostymulatora Asahi SL. Dawki środków zawarto w tabelach wynikowych. Na wszystkich obiektach zastosowano ochronę fungicydową z użyciem preparatu Duett Ultra 497 SC (tiofanat metylu + epoksykonazol) w fazie zakrywania międzyrzędzi.

Selektywność preparatów względem rośliny uprawnej oceniano kilkakrotnie (według przyjętej metodyki EPPO), posługując się skalą procentową (0-100), gdzie 0 - oznacza brak znak fitotoksycznego oddziaływania, a 100 całkowite zniszczenie roślin.

Po zebraniu plonu wykonano analizę jego wielkości i struktury. Metody oceny plonu polegały na określeniu plonu korzeni oraz liści buraka cukrowego oraz zawartości takich składników jakościowych, jak: cukier, potas, sód i azot. Pomiary parametrów jakościowych korzenia wykonano w Cukrowni Pfeifer \& Langen w Środzie Wielkopolskiej.

Analizie statystycznej poddano obsadę roślin na $1 \mathrm{~m}^{2}$, masę korzeni i liści (z 50 roślin ze środkowych 2 rzędów) oraz wybranych parametrów jakościowych buraka cukrowego. Po stwierdzeniu istotnych różnic dokonano szczegółowego porównania średnich za pomocą testu t-Studenta, wyznaczając najmniejszą istotną różnicę na poziomie istotności 0,05 .

\section{Wyniki i dyskusja / Results and discussion}

W 2011 roku odnotowano znaczny niedobór opadów w kwietniu (okres siewu), maju oraz sierpniu. Miesiące czerwiec i lipiec charakteryzowały się warunkami względnie wilgotnymi. W 2012 roku okres półsuszy wystąpił w kwietniu i maju, natomiast czerwiec i lipiec były miesiącami bardzo wilgotnymi.

W dwuletnich doświadczeniach stwierdzono bardzo wysoką skuteczność chwastobójczą wszystkich kombinacji doświadczalnych. Dodatek biostymulatora Aminoplant nie wpłynął na biologiczną aktywność herbicydów (wyniki nieprezentowane), jak i fitotoksyczne działanie na roślinę uprawną (tab. 1). Podobne wyniki uzyskano przy łącznym, jak i oddzielnym stosowaniu środka Aminoplant. W badaniach Kositorny i Smolińskiego (2008) odnotowano także brak wpływu łącznego stosowania herbicydów z biostymulatorem Asahi SL na skuteczność zwalczania chwastów jedno- i dwuliściennych w buraku cukrowym. 
Tabela 1. Wpływ stosowania nawozu organicznego Aminoplant na plonowanie buraka cukrowego

Table 1. Influence of application organic fertilizer Aminoplant on yield of sugar beet

\begin{tabular}{|c|c|c|c|c|c|c|c|c|c|}
\hline \multirow[t]{2}{*}{$\begin{array}{l}\mathrm{Nr} \\
\text { No. }\end{array}$} & \multirow[t]{2}{*}{$\begin{array}{c}\text { Obiekt } \\
\text { Treatment }\end{array}$} & \multirow[t]{2}{*}{$\begin{array}{c}\text { Dawka na ha } \\
\text { Dose per ha } \\
{[1 / \mathrm{g}]}\end{array}$} & \multirow[t]{2}{*}{$\begin{array}{c}\text { Termin } \\
\text { Date }\end{array}$} & \multicolumn{2}{|c|}{\begin{tabular}{|c|} 
Fitotoksyczność \\
Phytotoxicity \\
{$[\%]$}
\end{tabular}} & \multicolumn{2}{|c|}{$\begin{array}{l}\text { Plon korzeni } \\
\text { z } 50 \text { roślin } \\
\text { Root yield } \\
\text { from } 50 \text { plants } \\
\quad[\mathrm{kg}]\end{array}$} & \multicolumn{2}{|c|}{$\begin{array}{l}\text { Plon liści } \\
\text { z } 50 \text { roślin } \\
\text { Leaf yield } \\
\text { from } 50 \text { plants } \\
\quad[\mathrm{kg}]\end{array}$} \\
\hline & & & & 2011 & 2012 & 2011 & 2012 & 2011 & 2012 \\
\hline 1 & $\begin{array}{l}\text { a) Betanal Elite } 274 \mathrm{EC}+\text { Safari } 50 \mathrm{WG} \\
\text { b) Betanal Elite } 274 \mathrm{EC}+\text { Safari } 50 \mathrm{WG} \\
\text { c) Betanal Elite } 274 \mathrm{EC}+\text { Safari } 50 \mathrm{WG}\end{array}$ & $\begin{array}{l}1,0+30 \mathrm{~g} \\
1,0+30 \mathrm{~g} \\
1,0+30 \mathrm{~g}\end{array}$ & $\begin{array}{l}\mathrm{T} 3 \\
\mathrm{~T} 4 \\
\mathrm{~T} 5 \\
\end{array}$ & 0 & 0 & $25,4 \mathrm{a}$ & $41,5 \mathrm{a}$ & $13,9 \mathrm{a}$ & $19,5 \mathrm{a}$ \\
\hline 2 & $\begin{array}{l}\text { a) Betanal Elite } 274 \mathrm{EC}+\text { Safari } 50 \mathrm{WG} / \\
\text { Aminoplant } \\
\text { b) Betanal Elite } 274 \mathrm{EC}+\text { Safari } 50 \mathrm{WG} / \\
\text { Aminoplant } \\
\text { c) Betanal Elite } 274 \mathrm{EC}+\text { Safari } 50 \mathrm{WG} / \\
\text { Aminoplant }\end{array}$ & $\begin{array}{l}1,0+30 \mathrm{~g} / 1,5 \\
1,0+30 \mathrm{~g} / 1,5 \\
1,0+30 \mathrm{~g} / 1,5\end{array}$ & $\begin{array}{l}\mathrm{T} 3 / \mathrm{T} 3 \mathrm{a} \\
\mathrm{T} 4 / \mathrm{T} 4 \mathrm{a} \\
\mathrm{T} 5 / \mathrm{T} 5 \mathrm{a}\end{array}$ & 0 & 0 & $32,7 \mathrm{ab}$ & $49,5 \mathrm{ab}$ & $17,9 \mathrm{a}$ & $20,3 \mathrm{a}$ \\
\hline 3 & $\begin{array}{l}\text { a) Betanal Elite } 274 \mathrm{EC}+\text { Safari } 50 \mathrm{WG} \\
\text { + Aminoplant } \\
\text { b) Betanal Elite } 274 \mathrm{EC}+\text { Safari } 50 \mathrm{WG} \\
\text { + Aminoplant } \\
\text { c) Betanal Elite } 274 \mathrm{EC}+\text { Safari } 50 \mathrm{WG} \\
\text { + Aminoplant }\end{array}$ & $\begin{array}{l}1,0+30 \mathrm{~g}+1,5 \\
1,0+30 \mathrm{~g}+1,5 \\
1,0+30 \mathrm{~g}+1,5\end{array}$ & $\begin{array}{l}\mathrm{T} 3 \\
\mathrm{~T} 4 \\
\mathrm{~T} 5\end{array}$ & 0 & 0 & $29,3 \mathrm{ab}$ & $51,0 \mathrm{~b}$ & $15,6 \mathrm{a}$ & $20,5 \mathrm{a}$ \\
\hline 4 & $\begin{array}{l}\text { a) Betanal Elite } 274 \mathrm{EC}+\text { Safari } 50 \mathrm{WG} \\
+ \text { Aminoplant } \\
\text { b) Betanal Elite } 274 \mathrm{EC}+\text { Safari } 50 \mathrm{WG}+ \\
\text { Aminoplant + Basfoliar } 36 \text { Extra }+ \\
\text { ADOB Bor + ABOB Mn } \\
\text { c) BetanalElte } 274 \mathrm{EC}+\text { Safari } 50 \mathrm{WG}+ \\
\text { Aminoplant }\end{array}$ & $\begin{array}{l}1,0+30 \mathrm{~g}+1,5 \\
1,0+30 \mathrm{~g}+1,5 \\
+10+1+2 \\
1,0+30 \mathrm{~g}+1,5\end{array}$ & $\begin{array}{l}\mathrm{T} 3 \\
\mathrm{~T} 4\end{array}$ & 0 & 0 & $28,7 \mathrm{ab}$ & $46,2 \mathrm{ab}$ & $14,5 \mathrm{a}$ & $21,0 \mathrm{a}$ \\
\hline 5 & $\begin{array}{l}\text { a) Betanal Elite } 274 \mathrm{EC}+\text { Safari } 50 \mathrm{WG} \\
\text { + Aminoplant } \\
\text { b) Betanal Elite } 274 \mathrm{EC}+\text { Safari } 50 \mathrm{WG} \\
\text { c) Betanal Elite } 274 \mathrm{EC}+\text { Safari } 50 \mathrm{WG} \\
\text { + Aminoplant }\end{array}$ & $\begin{array}{c}1,0+30 \mathrm{~g}+1,5 \\
1,0+30 \mathrm{~g} \\
1,0+30 \mathrm{~g}+1,5\end{array}$ & $\begin{array}{l}\text { T3 } \\
\text { T4 } \\
\text { T5 }\end{array}$ & 0 & 0 & $33,3 \mathrm{ab}$ & $46,4 \mathrm{ab}$ & $15,9 \mathrm{a}$ & $20,5 \mathrm{a}$ \\
\hline 6 & $\begin{array}{l}\text { a) Betanal Elite } 274 \mathrm{EC}+\text { Safari } 50 \mathrm{WG} \\
\text { b) Betanal Elite } 274 \mathrm{EC}+\text { Safari } 50 \mathrm{WG} \\
\text { + Aminoplant } \\
\text { c) Betanal Elite } 274 \mathrm{EC}+\text { Safari } 50 \mathrm{WG} \\
\text { + Aminoplant }\end{array}$ & $\begin{array}{c}1,0+30 \mathrm{~g} \\
1,0+30 \mathrm{~g}+1,5 \\
1,0+30 \mathrm{~g}+1,5\end{array}$ & $\begin{array}{l}\text { T3 } \\
\text { T4 } \\
\text { T5 }\end{array}$ & 0 & 0 & $30,0 \mathrm{ab}$ & $50,4 \mathrm{~b}$ & $14,6 \mathrm{a}$ & $22,8 \mathrm{a}$ \\
\hline 7 & $\begin{array}{l}\text { a) Betanal Elite } 274 \mathrm{EC}+\text { Safari } 50 \mathrm{WG} \\
+ \text { Asahi } \\
\text { b) Betanal Elite } 274 \mathrm{EC}+\text { Safari } 50 \mathrm{WG} \\
+ \text { Asahi } \\
\text { c) Betanal Elite } 274 \mathrm{EC}+\text { Safari } 50 \mathrm{WG} \\
+ \text { Asahi }\end{array}$ & $\begin{array}{l}1,0+30 \mathrm{~g}+0,6 \\
1,0+30 \mathrm{~g}+0,6 \\
1,0+30 \mathrm{~g}+0,6\end{array}$ & $\begin{array}{l}\mathrm{T} 3 \\
\mathrm{~T} 4 \\
\mathrm{~T} 5\end{array}$ & 0 & 0 & $28,8 \mathrm{ab}$ & $45,1 \mathrm{ab}$ & $14,3 \mathrm{a}$ & $23,3 \mathrm{a}$ \\
\hline 8 & $\begin{array}{l}\text { a) Betanal Elite } 274 \mathrm{EC}+\text { Safari } 50 \mathrm{WG} \\
+ \text { Asahi } \\
\text { b) Betanal Elite } 274 \mathrm{EC}+\text { Safari } 50 \mathrm{WG} \\
\text { c) Betanal Elite } 274 \mathrm{EC}+\text { Safari } 50 \mathrm{WG} \\
\text { + Asahi }\end{array}$ & $\begin{array}{c}1,0+30 \mathrm{~g}+0,6 \\
1,0+30 \mathrm{~g} \\
1,0+30 \mathrm{~g}+0,6\end{array}$ & $\begin{array}{l}\text { T3 } \\
\text { T4 } \\
\text { T5 }\end{array}$ & 0 & 0 & $34,4 \mathrm{~b}$ & $45,7 \mathrm{ab}$ & $16,1 \mathrm{a}$ & $24,8 \mathrm{a}$ \\
\hline
\end{tabular}

Średnie oznaczone tymi samymi literami nie różnią się istotnie przy $\alpha=0,05$, test t-Studenta - the mean numbers with the same letter are not significantly different at $\alpha=0.05$, t-Student's test

Termin wykonania zabiegu: - Application time:

T3 - (BBCH 13-14) - w fazie 3-4 liści buraka: chwasty kiełkujące do fazy 2liści - sugar beet at the 3-4 leaf stage, germinating weeds to 2-leaf stage T3a - (BBCH 13-14) - maksymalnie jeden dzień po zabiegu T3 - maximally one day after T3

T4 - do 10-12 dni po zabiegu T3 (w fazie 5-6 liści buraka) - up to 10-12 days after T3 (sugar beet at the 5-6 leaf stage)

T4a - do 10-12 dni po zabiegu T3 (w fazie 5-6 liści buraka) - maksymalnie jeden dzień po zabiegu T4 - up to 10-12 days after T3 (sugar beet at the 5-6 leaf stage), maximally one day after T4

T5 - 8-12 dni po zabiegu T4 (w fazie 8-10 liści buraka), na ponowne wschody chwastów - 8-12 days after T4 (sugar beet at the 8-10 leaf stage), to reemergence weeds

T5a - 8-12 dni po zabiegu T4 (w fazie 8-10 liści buraka) - maksymalnie jeden dzień po zabiegu T5 - 8-12 days after T4 (sugar beet at the 8-10 leaf stage), maximally one day after T5 


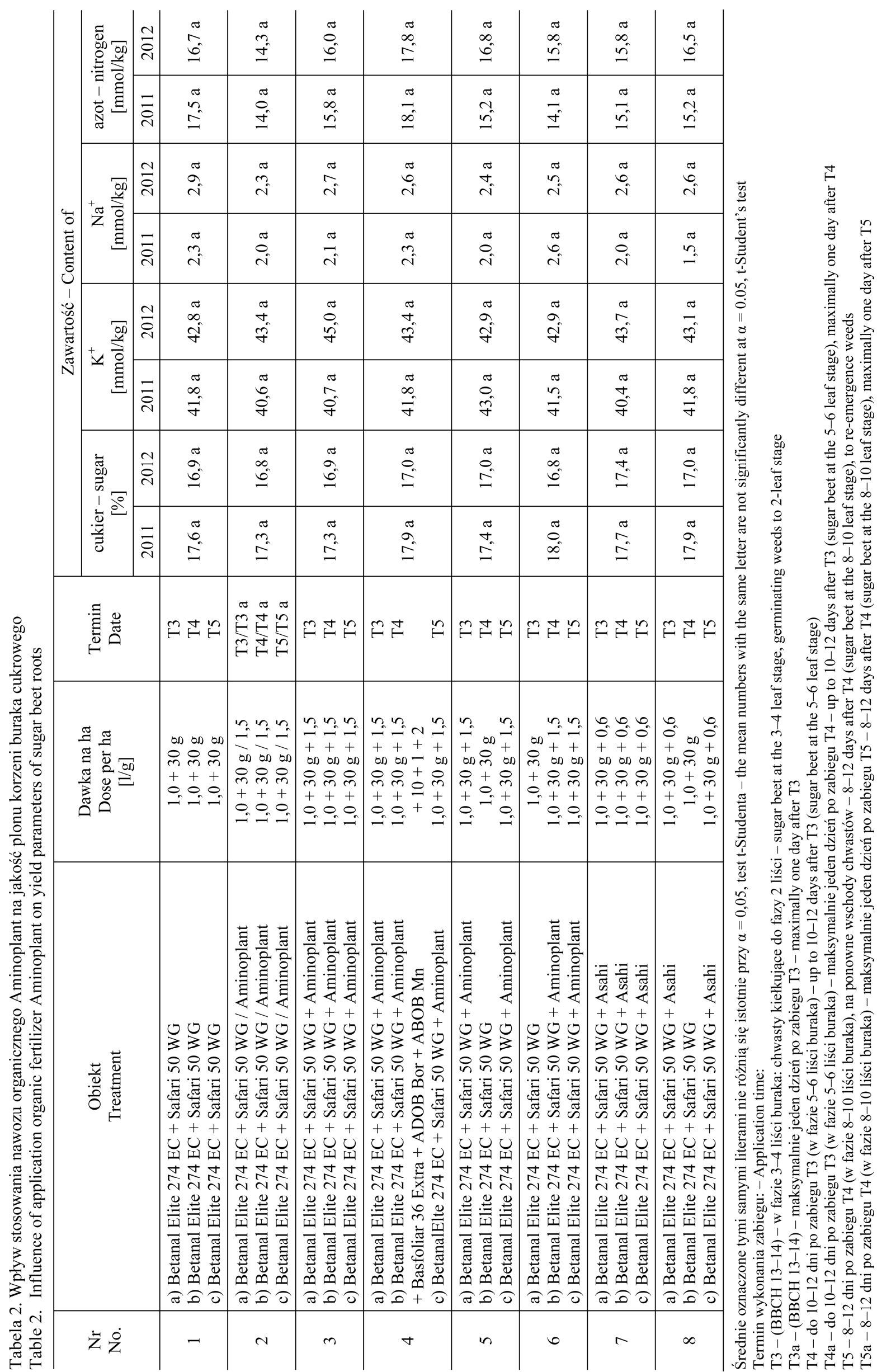


Wpływ stosowanego w doświadczeniu biostymulatora na rośliny buraka cukrowego określano na podstawie obsady roślin, masy korzeni i liści z 50 roślin oraz zawartości cukru, potasu, azotu i sodu w roślinie. Opierając się na wynikach z 2 lat prowadzonych obserwacji można stwierdzić, że wzrost plonu korzeni i liści buraka cukrowego wykazano dla wszystkich obiektów, w których zastosowano biostymulatory Aminoplant i Asahi SL. Dodatek środka Aminoplant powodował wyraźne zwiększenie wartości parametrów ilościowych buraka cukrowego, szczególnie plonu korzeni. Wzrost plonu korzeni $\mathrm{w}$ porównaniu do obiektu kontrolnego wynosił od 8,6 do $35,4 \%$, natomiast plonu liści od 2,8 do $28,7 \%$ (tab. 1). Podobne pozytywne wyniki $\mathrm{z}$ biostymulatorami uzyskali Kowalczyk i wsp. (2008), Łyszkowska i wsp. (2008), Kunicki i wsp. (2010) oraz Rosłon i wsp. (2011). $\mathrm{W}$ przeprowadzonych analizach istotny przyrost plonu korzeni stwierdzono w 2011 roku tylko w kombinacji, na której wykonywano zabiegi łącznego stosowania herbicydów z biostymulatorem Asahi SL (dwukrotnie w terminie T3 i T5). W 2012 roku statystycznie istotny przyrost plonu korzeni odnotowano natomiast $\mathrm{w}$ kombinacjach łącznego stosowania herbicydów ze środkiem Aminoplant, w których biostymulator stosowano trzykrotnie (terminy T3, T4 i T5) oraz dwukrotnie (T4 i T5). Tak zmienne dane mogły być wynikiem zróżnicowanego przebiegu warunków pogodowych w okresie wegetacji w obydwu latach badań. Reakcja roślin buraka na opryskiwanie biostymulatorami $\mathrm{w}$ różnych kombinacjach stosowania (termin, liczba i sposób aplikacji) była prawdopodobnie modyfikowana odmiennymi warunkami klimatycznymi i dostępnością składników pokarmowych w krytycznym dla wzrostu okresie wegetacji. Do podobnych wniosków doszli także Grabowska i wsp. (2012) w badaniach dotyczących oceny odmian i wpływu biostymulatora Aminoplant na wielkość i jakość plonu marchwi.

Uzyskane wyniki dają podstawę do stwierdzenia, że fizjologiczne właściwości biostymulatora Aminoplant są ściśle związane z zawartymi w nim aminokwasami, które są łatwo przyswajalne przez rośliny (Maini 2000), uczestniczą nie tylko $\mathrm{w}$ syntezie szeregu związków organicznych w roślinach, lecz także mają wpływ na pobieranie poszczególnych mikro- i makroelementów (Bytniewska 1985).

Przeprowadzone analizy chemiczne korzeni buraków dotyczyły procentowej zawartości cukru, a z uzyskanej miazgi określono $\mathrm{w}$ mmol/1000 g zawartość potasu, sodu i azotu. Stosowanie środka Aminoplant w różnym systemie aplikacji (dwukrotnie, trzykrotnie, pojedynczo i w mieszaninie $\mathrm{z}$ herbicydami) nie miało wpływu na zawartość cukru w buraku (tab. 2). Korzystne działanie tego środka na wzrost zawartości cukru z kolei stwierdzili Maini (1983) i Łyszkowska (2008) w doświadczeniach prowadzonych na owocach winorośli i sałacie.

W 2012 roku oddzielne stosowanie biostymulatora Aminoplant wpłynęło na niewielkie obniżenie parametrów jakościowych korzeni buraka cukrowego, szczególnie zawartości sodu i azotu (nie zostało to jednak udowodnione statystycznie). W obu latach badań zwiększona zawartość azotu odnotowano na obiekcie, na którym poza środkiem Aminoplant zastosowano dodatkowo nawozy dolistne $-6,5 \%$ wzrost w stosunku do kontroli (tab. 2).

Cambri i wsp. (2008) na podstawie danych uzyskanych z badań genetycznych roślin Arabidopsis thaliana L. twierdzą, że na poziomie molekularnym, Aminoplant stymuluje reakcję obronną rośliny na biotyczne i abiotyczne czynniki stresowe. Badania wykazały, że traktowanie roślin biostymulatorem Aminoplant indukuje zmiany $\mathrm{w}$ kierunku podwyższenia poziomu ekspresji genów. Produkty tych genów uczestniczą w reakcjach obronnych roślin przed stresami zarówno biotycznymi np. podczas patogenezy, jak i abiotycznymi, jak na przykład przed stresem suszy, osmotycznym oraz chłodu. Zostało to również zauważone przez Bytniewską (1985), która dodatkowo stwierdziła, że Aminoplant zmniejsza straty spowodowane przez wirusy i grzyby.

Przedstawione wyniki pozwalają sądzić, że Aminoplant jest środkiem podnoszącym naturalną odporność roślin poprzez pobudzanie wrodzonych reakcji obronnych, stymulując wzrost i rozwój wielu gatunków roślin (Bytniewska 1985; Cambri i wsp. 2008). Korzystne działanie biostymulatora na rośliny uprawne może uwidocznić się szczególnie w warunkach stresowych, jak np. susza i po stosowaniu herbicydów powodujących okresowy „stres herbicydowy”, czyli przemijające objawy uszkodzeń lub zahamowanie wzrostu roślin (Anyszka i wsp. 2008).

W badaniach stwierdzono, że dwukrotne lub trzykrotne stosowanie nawozu Aminoplant, a także zabiegi pojedyncze i łączne $\mathrm{z}$ herbicydami odznaczają się podobnym wpływem na efekty plonotwórcze buraka cukrowego. Mimo, że tylko w drugim roku badań stwierdzono korzystny wpływ biostymulatora Aminoplant na parametry ilościowe plonu korzeni, to na podstawie uzyskanych wyników trudno jest jednoznacznie określić optymalną liczbę zabiegów i termin ich wykonania. Wystarczającym wydaje się stosowanie dwóch zabiegów środkiem Aminoplant w zabiegach łącznych $\mathrm{z}$ herbicydami (od fazy 3 liści buraka) w odstępie 3-4 tygodni. Istotne znaczenie na uzyskiwany efekt plonotwórczy ma przebieg warunków pogodowych przed i po aplikacji biostymulatora, a także inne czynniki związane z warunkami glebowymi, czy też dostępnością substancji odżywczych. Uzyskane wyniki dowodzą także, że można spodziewać się korzystnego działania biostymulatora Aminoplant w warunkach zbliżonych do optymalnych dla wzrostu roślin.

\section{Wnioski / Conclusions}

1. Stosowanie biostymulatora Aminoplant w łącznych zabiegach z herbicydami Betanal Elite 274 EC + Safari 50 WG wpłynęło korzystnie na wielkość plonu korzeni buraka cukrowego, natomiast nie miało istotnego wpływu na takie parametry jakościowe korzeni buraka, jak: zawartość cukru, azotu, potasu i sodu.

2. W badaniach stwierdzono, że preparat Aminoplant nie miał wpływu na efektywność chwastobójczą i fitotoksyczność herbicydów w stosunku do roślin buraka cukrowego. 
3. Nie stwierdzono różnic $w$ efektach działania środka Aminoplant na rośliny buraka cukrowego, w zależności od liczby zabiegów (dwu- i trzykrotne) oraz oddzielnej lub łącznej aplikacji z herbicydami.

4. Termin stosowania środka Aminoplant i liczbę zabiegów należy dostosować do możliwości chemicznej ochrony przed chwastami i odpowiedniej fazy rozwojowej buraka cukrowego.
5. Zmienna reakcja buraka cukrowego na nalistne stosowanie biostymulatora Aminoplant w zabiegach łącznych $\mathrm{z}$ herbicydami mogła być modyfikowana przebiegiem wegetacji i warunkami klimatycznymi.

6. Łączne stosowanie biostymulatora Aminoplant $\mathrm{z}$ herbicydami w uprawie buraka cukrowego daje wymierne korzyści w postaci ograniczenia liczby dodatkowych zabiegów ochronnych.

\section{Literatura / References}

Anyszka Z., Dobrzański A., Pałczyński J. 2008. Response of onion and carrot to Asahi SL biostimulator used with herbicides. p. 7-20. In: "Biostimulators in Modern Agriculture. Vegetable Crops" (Z. Dąbrowski, ed.). Wieś Jutra, Warszawa, 83 pp.

Bytniewska K. 1985. Siapton - dolistny nawóz. Post. Nauk Rol. 32 (5): 27-36.

Cambri D., Filippini L., Apone F., Arciello S., Colucci G., Portoso D. 2008. Effect of Aminoplant ${ }^{\circledR}$ on expression of selected genes in Arabidopsis thaliana L. plants. p. 77-82. In: "Biostimulators in Modern Agriculture. General Aspects" (H. Gawrońska, ed.). Wieś Jutra, Warszawa, $89 \mathrm{pp}$.

Grabowska A., Kunicki E., Sękara A., Kalisz A. 2012. The effect of cultivar and biostimulant treatment on the carrot yield and its quality. Veg. Crops Res. Bull. 77: 37-48.

Gawrońska H., Przybysz A. 2011. Biostymulatory: mechanizmy działania i przykłady zastosowań. s. 7-13. W: Mat. Konferencyjne „Targi Sadownictwa i Warzywnictwa”. Agrosimex Sp. z o.o., War-szawa, 5-6.01.2011, 70 ss.

Kositorna J., Smoliński M. 2002. Badania nad przydatnością środków przeciw stresowych do stosowania z herbicydami nalistnymi. Poradnik Plantatora Buraka Cukrowego 4: 12-14.

Kositorna J., Smoliński M. 2008. Asahi SL biostymulator in protection of sugar beet from herbicide stress. p. 41-49. In: "Biostimulators in Modern Agriculture. Field Crops" (Z.T. Dąbrowski, ed.). Wieś Jutra, Warszawa, 118 pp.

Kowalczyk K., Zielony T., Gajewski M. 2008. Effect of Aminoplant and Asahi field and quality of lettuce grown on rockwool. p. 35-43. In: "Biostimulators in Modern Agriculture. General Aspects" (H. Gawrońska, ed.). Wieś Jutra, Warszawa, 89 pp.

Krajewska J., Latkowska M. 2008. The effects of biostimulants Asahi SL and Siapton $10 \mathrm{~L}$ on the growth of Bergenia cordifolia (Haw.) Sternb. 'Rotblum' and Hosta sp. (Tratt.) 'Sum and substance' and 'Minuteman'. p. 33-39. In: "Biostimulators in Modern Agriculture. Ornamental and Special Crops (A. Łukaszewska, ed.). Wieś Jutra, Warszawa, 68 pp.

Kunicki E., Grabowska A., Sękara A., Wojciechowska R. 2010. The effect of cultivar type, time of cultivation, and biostimulant treatment on the yield of spinach (Spinacia oleracea L.). Folia Hortic. 22 (2): 9-13.

Łyszkowska M., Gajc-Wolska J., Kubiś K. 2008. The influence of biostimulators on yield and quality of Lear and iceberg lettuce grown under field conditions. p. 28-34. In: "Biostimulators in Modern Agriculture. Vegetable Crops" (Z. Dąbrowski, ed.). Wieś Jutra, Warszawa, 83 pp.

Maini P. 1983. Ricerche di laboratorio e di campo con un prodotto naturale organico complesso ad applicazione fogliare. Vignevini 10 (3): 58-62.

Maini P. 2000. The experience of the first biostimulant, based on amino acids and peptides: a short retrospective review on the laboratory researches and the practical results. Fertilitas Agrorum 1 (1): 29-43.

Przybysz A., Wrochna M., Słowiński A., Gawrońska H. 2010. Stimulatory effect of Asahi SL on selected plant species. Acta Sci. Pol., Hortorum Culturs 9 (2): 53-64.

Rosłon W., Osińska E., Bączek K., Węglarz Z. 2011. The influence of organic-mineral fertilizers on field and raw materials quality of chose plant of the Lamiaceae family from organic cultivation. Acta Sci. Pol., Hortorum Cultus 10 (1): 147-158. 